\title{
Carnets
}

Revue électronique d'études françaises de l'APEF

Première Série - 3| 2011

$\mathrm{L}^{\prime}($ In)vraisemblable

\section{(In)verosímil e fantástico ou a arte de provocar o medo}

Ana Alexandra Seabra De Carvalho

\section{OpenEdition}

1 Journals

\section{Edição electrónica}

URL: http://journals.openedition.org/carnets/5958

DOI: 10.4000/carnets.5958

ISSN: 1646-7698

\section{Editora}

APEF

\section{Edição impressa}

Data de publição: 2 Janeiro 2011

Paginação: 71-97

\section{Refêrencia eletrónica}

Ana Alexandra Seabra De Carvalho, "(In)verosímil e fantástico ou a arte de provocar o medo », Carnets [Online], Première Série - 3 | 2011, posto online no dia 18 junho 2018, consultado o 03 maio 2019. URL : http://journals.openedition.org/carnets/5958; DOI : 10.4000/carnets.5958

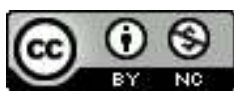

Carnets est mis à disposition selon les termes de la licence Creative Commons - Atribution - Pas d'utilisation commerciale 4.0 International. 


\title{
(IN)VEROSÍMIL E FANTÁSTICO OU A ARTE DE PROVOCAR O MEDO
}

Ana Alexandra Seabra de Carvalho

FCHS - Universidade do Algarve e CLEPUL

aacarva@ualg.pt

\section{Resumo}

Filho do lluminismo, o fantástico recusa igualmente a inverosimilhança do maravilhoso e a verosimilhança aristotélica do Classicismo ou do Realismo. Real e irreal entrelaçam-se, originando perturbação, mistério e angústia. Privada de Deus, a realidade humana é percepcionada como enigmática e inquietante. Para provocar no leitor o efeito da angústia e do medo, o fantástico assenta na ambiguidade da apresentação do fenómeno meta-empírico, inserindo, num quadro real verosímil, algo de escandalosamente inverosímil que instaura o paradoxo nos quadros de referência do mundo conhecido. Como explicar o sucedido? As respostas de Crébillon, Baudelaire ou Maupassant aqui tratadas serão diferentes. Contudo, depois de Todorov, aceita-se que o maravilhoso crê no sobrenatural, a ficção científica desenvolve uma fantasia baseada nos poderes racionais da ciência e o estranho encontra uma solução racional. No fantástico - construído a partir da incerteza e da ambiguidade - devem permanecer a hesitação, a perplexidade, a angústia e o medo.

\begin{abstract}
Child of the Enlightenment, fantastic literature refuses both the lack of truthlikeness of imaginary fiction and the Aristotelian verisimilitude present in classical and realistic literature. Real and unreal mingle together, originating anxiety, mystery and anguish. Deprived from God, human reality is perceived as puzzling and disturbing. To provoke anguish and fear in the reader, fantastic fiction makes use of ambiguity in the presentation of the meta-empirical phenomenon, by inserting on a real and likely frame of reference something scandalously unlikely, which sets the paradox on the frames of reference of the known world. How to explain the event? The answers here studied given by Crébillon, Baudelaire or Maupassant differ. However, after Todorov, it is accepted that imaginary fiction believes in supernatural, science fiction develops a fantasy based on the rational powers of science and strange fiction finds a rational solution. In fantastic fiction - built from uncertainty and ambiguity hesitation, perplexity, anguish and fear must remain.
\end{abstract}

Palavras-chave: Verosimilhança, Fantástico, Ambiguidade, Angústia e Medo

Keywords: Verisimilitude, Fantastic, Ambiguity, Anguish and Fear 
I.

A partir do final do séc. XVIII, assiste-se, no contexto europeu - e, nomeadamente, em França -, ao desenvolvimento de um tipo de texto literário que, após 1830, seria caracterizado, por Charles Nodier, como fantástico. Trata-se de narrativas - contos, novelas ou romances - que se apresentam como uma reacção aos excessos racionalistas e materialistas da filosofia das Luzes, bem como ao crescente deslocamento da fé do âmbito do poder divino (e diabólico) para o das potencialidades da inteligência humana tal como se manifestam nos progressivos avanços científicos e tecnológicos. Os exemplos inaugurais do género fantástico pertencem à literatura francesa e são Le Diable amoureux, de Jacques Cazotte (1772), e Manuscrit trouvé à Saragosse, de Jean Potocki (1804-1814), brilhantes encenações de assustadoras possessões diabólicas. Neste nosso estudo, procuraremos abordar o modo como a narrativa fantástica utiliza os conceitos aristotélicos de verosímil e inverosímil para construir um discurso ambíguo, onde o fingimento da verdade está ao serviço de uma literatura da perplexidade inquietante que provoca o medo face a fenómenos extra-ordinários inexplicáveis.

Relativamente ao conceito de fantástico são conhecidas várias definições canónicas que procuram caracterizá-lo: Castex (1951), Caillois (1965), Vax (1972), Todorov (1977), Bessière (1974), Furtado (1980), Bozzetto et al. (1980), Schneider (1985), entre outros. Sintetizando estas várias contribuições, podemos dizer que o fantástico pressupõe que o real abra alguma fenda, isto é, que se instaure a desordem e o caos num mundo ordenado. O fantástico é comunhão paradoxal das leis da natureza e do caos, transgressão da organização das categorias aceites; ele é também oscilação entre o real e o irreal, entre o racional e o irracional; irrupção escandalosa e, porém, evidente; a solução é sempre insatisfatória. Ou seja, na narrativa fantástica, real e irreal entrelaçam-se, criando um crescente efeito retórico de perturbação, mistério e angústia. O herói, incrédulo, sente a "inquietante estranheza" (Freud) da perturbação da ordem natural provocada por uma manifestação ambiguamente tenebrosa e maléfica que irrompe bruscamente na sua realidade quotidiana e familiar. Privada de Deus, a realidade humana é vista, então, como enigmática e inquietante. De facto, o fantástico é, sobretudo, uma questão de percepção: para provocar no leitor o efeito da angústia e do medo, a narrativa fantástica assenta na ambiguidade da apresentação do fenómeno meta-empírico, fingidamente verdadeiro, inserindo, assim, num quadro real verosímil, algo de escandalosamente inverosímil que instaura o paradoxo nos quadros de referência do mundo conhecido, podendo conduzir à loucura ou/e à morte.

Vemos, assim, que, na narrativa fantástica, a acção se centra nos fenómenos ou seres insólitos, aparentemente de natureza sobrenatural. Mas então como explicar o 
sucedido? Dos seus alvores até ao século XIX, a literatura foi dando respostas diferenciadas, como veremos adiante com exemplos de Crébillon, Baudelaire e Maupassant. No plano teórico e segundo Todorov ${ }^{1}$, no género maravilhoso, verifica-se uma aceitação plena da explicação sobrenatural - intervenção mágica, divina ou diabólica. A ficção científica, por seu turno, encena uma fantasia associada à crença nos super-poderes racionais da ciência humana. No estranho, oscila-se entre a crença no sobrenatural ou na solução racional, verificando-se, no fim, a prevalência da última. Contudo, a resposta, no género fantástico, construído a partir da incerteza ${ }^{2}$ e da ambiguidade ${ }^{3}$, é a da hesitação, da perplexidade, da angústia e do medo: o protagonista não sabe o que pensar, apenas sabe que aconteceu o impossível e que não está louco, ou estará? - Decida o leitor (se puder). O fantástico, no sentido todoroviano, afasta-se, então, por um lado, da inverosimilhança pressuposta mas totalmente aceite pelo pacto ficcional do maravilhoso, característico do imaginário mítico, místico, lendário, fabuloso, feérico ou tenebroso. Todavia, ele distanciase, igualmente, por outro lado, do imperativo da verosimilhança absoluta que, de Aristóteles ao Classicismo (seiscentista e setecentista) e, já no séc. XIX, à estética realista, enforma o pacto ficcional das várias manifestações do "realismo" na literatura francesa e europeia.

Como é bem sabido, o pensamento teocêntrico medieval aceita o plano sobrenatural em íntima relação com o plano do real, coexistindo em harmonia e explicando-se mutuamente, o que corresponde às leis do maravilhoso. Aliás, até ao final do século XVII, a crença na bruxaria, por exemplo, fez com que tanto o senso comum como a lei condenassem à fogueira muitas pessoas acusadas de pacto comprovado com o demónio. Por outro lado, este é o momento em que se inaugura, na literatura francesa, com Charles Perrault, o período áureo dos contos de fadas, reino do maravilhoso por excelência. Só com - lluminismo setecentista se começa a pôr em causa a aceitação da verosimilhança da interferência do sobrenatural no plano da vida real quotidiana, rompendo-se, assim, o equilíbrio anterior e proporcionando-se o surgimento de uma nova tipologia de textos sobre fenómenos sobrenaturais, onde a dúvida se instala. Como refere Irène Bessière a este propósito:

Lorsque le vraisemblable d'une culture donnée semble (est) soudain privé de sens, le lien de l'œuvre aux éléments extra-textuels installe l'arbitraire et l'inconséquence. Jusqu'au XVIIle siècle, le vraisemblable se charge simultanément du discours sur la nature et du discours sur la surnature, que la religion assemble de manière cohérente. Avec les Lumières, ces deux discours deviennent antinomiques, la culture est

\footnotetext{
${ }^{1}$ Cf. Todorov (1977).

${ }^{2}$ Cf. Bessière (1974).

${ }^{3}$ Cf. "No essencial, a narrativa fantástica deverá propiciar através do discurso a instalação e a permanência da ambiguidade de que vive o género, nunca evidenciando uma decisão plena entre o que é apresentado como resultante das leis da natureza e o que surge em contradição frontal com elas" (Furtado, 1980: 132).
} 
incapable de les concilier. Dans ce moment transitoire de déséquilibre, apparaît le récit fantastique [...] (Bessière, 1974: 67-68)

A antinomia referida permite ao leitor uma reacção de perplexidade quando o metaempírico irrompe bruscamente no quadro do mundo real e das suas leis naturais. Contudo, o pensamento iluminista também não o exclui em absoluto, o que, segundo Filipe Furtado, "mantém completamente aberta a via para a indecisão permanente de que vive o fantástico" (Furtado, 1980: 136). Assim, para conseguir o difícil equilíbrio que caracteriza este género, a organização narrativa deve corresponder, ainda de acordo com F. Furtado, aos seguintes traços: em primeiro lugar, como já dissemos, ela deve, num contexto aparentemente normal, fazer irromper e tornar "dominantes em relação aos restantes elementos temáticos acontecimentos ou personagens que subentendam a existência objectiva de uma fenomenologia meta-empírica e evidenciem índole e propósitos considerados negativos à luz dos padrões axiológicos correntes" (Furtado, 1980: 132). Depois, a organização narrativa deve conferir verosimilhança a tais fenómenos, de forma a, paradoxalmente, torná-los aceitáveis pelo senso comum e pelas regras do género. Para que funcione, essa inverosimilhança tem de ser ocultada através de processos que salientem o seu aspecto... verosímil. Em terceiro lugar, o autor supracitado refere a necessidade de jogar com explicações meramente parcelares dos fenómenos insólitos para evitar cair na racionalização plena do estranho ou na ausência de tentativa de racionalização que pressupõe a sua aceitação sem reservas própria do maravilhoso ${ }^{4}$. Há ainda um conjunto de aspectos a considerar na caracterização do género fantástico. Para F. Furtado, a narração deverá estar a cargo de um narrador fiável, céptico, preferencialmente homodiegético (testemunha dos factos) ou mesmo autodiegético (protagonista) que tenha autoridade perante o leitor e lhe transmita a perplexidade, a angústia e o medo. Este aspecto será tanto mais conseguido se existir no texto um narratário preferencialmente intradiegético com a dupla função de reflectir a leitura incerta dos fenómenos meta-empíricos e transmitir ao leitor idênticas reacções perante os factos inexplicáveis. O fantástico, centrando-se, então, na paradoxal subversão do real por fenómenos na aparência sobrenaturais, encena geralmente personagens planas que suscitam a identificação do leitor e permitem a representação da percepção ambígua dos fenómenos insólitos. Elas devem, pois, agir num "espaço híbrido, indefinido, que, aparentando sobretudo representar o mundo real, contenha indícios da própria subversão deste e a deixe insinuar-se aos poucos" (Furtado, 1980: 132-133).

Atentemos agora mais concretamente nos aspectos da verosimilhança e da inverosimilhança no seio do género do fantástico, aquilo a que F. Furtado chamou "a falsidade verosímil” (Furtado, 1980: 44). Como já foi referido, na narrativa fantástica surge

\footnotetext{
${ }^{4}$ Cf. Furtado (1980: 132).
} 
um universo em que apenas algumas categorias do real foram transformadas ou suprimidas, instaurando-se uma antinomia insólita e assustadora, pois não permite que uma explicação racional venha restaurar a lógica das leis da natureza conhecida. Assim, o fantástico, ao contrário do maravilhoso,

procura nunca proporcionar ao receptor do enunciado uma certeza total sobre o teor do mundo em que é imerso, mundo esse que lhe parece o normal (embora nele se insinue a subversão da normalidade) e cujo carácter "descontínuo" leva a constantes reavaliações da pseudo-realidade que Ihe é proposta. (Furtado, 1980: 44)

Verifica-se, então, a hesitação oscilante entre aceitar ora o sobrenatural, ora uma explicação lógica. Para produzir a aceitação verosímil da inverosímil antinomia sobrenatural vs. real, o fantástico tem de falsear os dados: "a coberto [desta verosimilhança], o receptor do enunciado será conduzido, como que pela mão, a quase aceitar que a subversão das leis naturais que a sua razão recusa é uma séria possibilidade no mundo falsamente normal em que o fantástico o mantém isolado" (Furtado, 1980: 45). Ora, como sabemos, o verosímil é um simulacro da verdade. Como tal, ele apenas se adequa à ideia que dele faz a opinião pública e às exigências das regras de cada género literário, variáveis naturalmente mutáveis de acordo com as diferentes épocas e paragens. Deste modo, se, como afirma F. Furtado, o fantástico, "aparenta conformar-se com os dados da opinião corrente no enquadramento epocal e ideológico em que a narrativa é produzida, utilizando-os para tornar admissíveis as personagens e o espaço alegadamente reais em que a ocorrência insólita irá surgir" (Furtado, 1980: 48), ele utiliza, sobretudo, o plano do verosímil correspondente ao respeito integral das regras do género "para tornar plausíveis os elementos extranaturais em si" (48). Mas, como salienta ainda o autor, estes elementos sobrenaturais, se são tidos pela doxa como inverosímeis, podem, contudo, "revelar-se inteiramente aceitáveis se forem considerados à luz dos princípios específicos que governam o género, em particular aqueles que decorrem da própria atitude do fantástico perante o sobrenatural" (48-49). Para além disso, o género fantástico joga com a verosimilhança para tentar suscitar no leitor o mesmo tipo de obediência cega às convenções genológicas que estão na base da construção da narrativa, "procurando fazer crer que aquilo que somente resulta da aplicação dessas convenções e está em frontal contradição com a opinião comum não só não hostiliza esta, mas é afinal um dos possíveis da própria realidade" (53). No entanto, a manutenção da verosimilhança textual depende, em larga medida, da capacidade de ocultação de tais processos retórico-literários ${ }^{5}$, pois é necessário "mascarar a efectiva inadequação da

\footnotetext{
${ }^{5}$ Alguns desses processos, que estudaremos adiante nos exemplos textuais escolhidos, podem desde já ser referidos em termos gerais. São eles: o recurso à autoridade, isto é, trata-se de fornecer dados fictícios mas
} 
história ao mundo empírico", isto é, a sua inverosimilhança, "fazendo esquecer que ela apenas contém uma lógica (a do género) cujas regras se pretende impor ao destinatário" (53).

Assim, o "efeito de real" (conceito barthesiano bem conhecido) é absolutamente imprescindível na narrativa fantástica de forma a, paradoxalmente, fazer irromper e tornar admissível a aparência sobrenatural dos fenómenos encenados. Daqui resulta o delicado equilíbrio da ambiguidade estrutural que caracteriza o género.

II.

Propomos agora a consideração de três obras da literatura francesa ligadas, em nosso entender, por uma linha evolutiva que vai do conto maravilhoso ao conto fantástico todoroviano, ou seja, Le Sylphe, de Claude Crébillon, alguns exemplos de poemas em prosa de Baudelaire inseridos em Le Spleen de Paris e, finalmente, o conto Apparition, de Maupassant.

Em primeiro lugar, e no que diz respeito aos aspectos da verosimilhança e da inverosimilhança, atentemos, num momento singular que, a nosso ver, pode constituir uma interessante forma de transição entre o pacto ficcional do conto maravilhoso e o do fantástico. Referimo-nos ao texto inaugural de Claude Crébillon, intitulado significativamente Le Sylphe, ou songe de Madame de $R^{* * *}$ écrit par elle-même à Madame de $S^{* \star *}$ (Crébillon, 1999), publicado em 1730 sem nome de autor, o que pode corresponder ao código da verosimilhança da ficção da autenticidade e do anonimato do romance epistolar, em voga em França desde o final do século XVII, após o sucesso das Lettres portugaises.

A narrativa, paradoxalmente breve em relação à extensão do título, é composta por uma carta-confidência trocada entre duas mulheres ${ }^{6}$, as Senhoras de $R^{* \star *}$ (a epistológrafa) e a de $S^{\star * *}$ (sua destinatária e amiga), cujos nomes surgem reduzidos a uma inicial seguida de asteriscos e à marca distintiva da pertença à classe aristocrática (de). Este procedimento

atribuídos a fontes credíveis, por exemplo, o testemunho de personagens respeitáveis (pela idade, pelo conhecimento, pelo estatuto social); a apresentação de documentos fiáveis (ou, como no caso do Manuscrit trouvé à Saragosse, o valor do documento encontrado por acaso e anónimo, fazendo com que o verosímil da falsidade englobe toda a narrativa, o que escusa o narrador-editor de $1^{\circ}$ nível de se justificar perante a aceitação ou não do insólito, reforçando a ambiguidade). Podemos ter também a mistura de dados conhecidos e verídicos com outros falsos ou a distorção de dados verdadeiros. A verosimilhança pode, pois, ser também criada através de referências factuais que envolvem factos ou fenómenos do real relacionados com vários domínios do conhecimento: factos históricos ou contemporâneos da narrativa; ou dados pseudo-científicos ou filosóficos. Surgem frequentemente misturados com outros fictícios. Deste modo, procura-se fazer passar a credibilidade/verosimilhança para o lado do inexplicável (cf. Furtado,1980: 54-56). Por seu turno, a racionalização apenas parcial "não desfaz a manifestação insólita e cria uma ilusão de confiança na imparcialidade do narrador" (Furtado, 1980: 67). Ela deve ainda relacionar-se com a acentuação do efeito de real do espaço onde decorre a acção, o efeito de recuo temporal e/ou deslocação espacial e a confirmação pseudo-científica ou filosófica (cf. Furtado,1980: 57-58). Acrescentemos, ainda, ao nível do discurso, o recurso constante à forma do Imperfeito, ao modo Condicional e à modalização.

${ }^{6}$ Este tipo de texto permite a adopção do tom feminino de uma conversa galante, divertida e plena de graça espirituosa sem ferir as regras da verosimilhança. 
visa atestar, com verosimilhança, a autenticidade das personagens e do texto-documento, cuja autoria é atribuída a Mme de $\mathrm{R}^{\star \star *}$, delegando-se nela, portanto, a inteira responsabilidade quanto ao conteúdo da missiva. De acordo com o título, ele tanto pode dizer respeito a um elemento esotérico, um silfo, como a um sonho, uma ilusão ou um devaneio. Com esta apresentação estratégica, uma voz feminina é colocada em primeiro plano, escondendo, porém, uma outra voz, a de um inominado "editor", igualmente uma máscara da voz autoral. De facto, é a voz anónima de um suposto editor que apresenta o título do texto epistolar de que o leitor encetou a leitura, sendo também responsável pelo anonimato decoroso relativo às duas personagens femininas. Deste modo, a instância autoral segue as regras do protocolo retórico da ficção epistolar apresentada como documento autêntico. Ou seja, aqui parece verificar-se o respeito pelas regras genológicas, apesar de o texto pôr em cena uma personagem cuja existência real o racionalismo do seu tempo procura enjeitar. Mais adiante voltaremos a esta questão. Para já, diga-se que, em toda a obra de Crébillon, a palavra dialogada assume um papel preponderante como meio de análise sentimental e como jogo de sedução e de poder. O primeiro exemplo verifica-se logo neste texto inaugural, onde se põe em cena uma conversa jocosa, com grandes probabilidades de mistificação por parte da epistológrafa, travada entre a voz de um ser masculino que se apresenta como silfo libertino e a jovem condessa que se diz fascinada por tais entidades esotéricas. Aparentemente, então, aceita-se a existência de criaturas maravilhosas. O colóquio versa, por um lado, sobre o imperativo da sedução e da inconstância resultante da saciedade e do desdém e, por outro, sobre a posse e a sua impossibilidade, assim se colocando a questão do desejo amoroso sob o signo do sonho, da ilusão e do devaneio (matéria fértil a explorar pelo autor nas suas obras posteriores).

No entanto, trata-se aqui de uma epístola singular: tanto pelo número, como pela forma - se esta única carta contém a narrativa de um encontro amoroso nocturno entre uma mulher e um suposto ser imaginário, ela é constituída, sobretudo, por um diálogo de sedução. Do ponto de vista formal, o texto combina, pois, a epístola, o conto e o diálogo, três das formas predilectas da narrativa setecentista. Contudo, o mais interessante é que tal combinatória permite o jogo ambíguo entre o real e o sobrenatural, problematizando as suas fronteiras. Mas ela contribui, ao mesmo tempo, para a problematização das fronteiras dos géneros narrativos. Temos, assim, ao nível da troca comunicativa, a ocorrência, em primeiro lugar, da interlocução do diálogo de sedução travado entre a Condessa e a voz do Silfo libertino. Este diálogo de sedução converte-se, em seguida, no assunto e na justificação da escrita da carta, em que, prontamente, a Condessa decide confidenciar-se à amiga e correspondente. Porém, qualquer troca epistolar privada corre sempre o risco de se tornar pública, facto explorado à exaustão pelos autores de romances por cartas da época nos seus avisos destinados aos leitores. Assim, ao nível da troca comunicativa, encontramos 
finalmente aqui o jogo literário entre a instância autoral e o seu leitor, no qual se propõe, de forma paradoxal, que este último aceite tanto as regras da narrativa epistolar - isto é, as da ficção verosímil da autenticidade do texto -, como eventualmente as do conto maravilhoso com todo o seu código de inverosimilhança. Deste modo, o leitor é levado a questionar-se: afinal, a que mundo pertence o sedutor da narrativa - ao mundo esotérico e cabalista dos espíritos aéreos ou ao mundo real, seja o de carne e osso, seja o das fantasias eróticas femininas?

Necessariamente breve, visto que se trata de uma carta, e evocando o espírito de um bibelot rococó pela sua graciosidade e elegância, tanto de espírito como de linguagem, este texto revela-se, no entanto, uma forma literária complexa pelo modo como harmoniza as convenções literárias de alguns dos géneros narrativos de maior sucesso junto do público do seu tempo. Assim, a monódia epistolar no feminino instaura a convenção da autenticidade do texto. Em contraponto, o silfo evocado no título remete o leitor para o universo do conto maravilhoso. Curiosamente, a epistológrafa, narradora autodiegética, parece, no entanto, hesitante quanto à crença em elementos esotéricos, sugerindo a explicação racional da hipótese onírica. Ora, como as convenções genológicas do conto maravilhoso exigem a aceitação plena da possibilidade de coexistência entre a ordem do real e a do sobrenatural, o texto pode transformar-se, contrariamente ao silfo do abade de Villars $^{7}$, num conto fantástico avant la lettre, consoante as decisões interpretativas dos diferentes leitores, sobretudo os do sexo feminino. Finalmente, o género do diálogo, neste caso, de sedução, é o que predomina no texto, invadindo o espaço e as convenções dos anteriormente referidos, permitindo até a mistura entre a narrativa e o teatro. Assim, desde o primeiro momento, o autor instaura as suas predilecções em matéria de géneros narrativos e suas possibilidades combinatórias.

Os elementos cabalistas e esotéricos, tais como silfos e sílfides, suscitam no público setecentista um grande interesse - que começara, aliás, a partir do ano de 1670, ou seja, após a publicação da obra do abade Montfaucon de Villars, intitulada Le Comte de Gabalis, sátira das doutrinas ocultistas. Esse interesse é aproveitado pelo jovem Crébillon, em $L e$ Sylphe, para, sob a aparência do conto fantástico ocultista, cuja moda ele acabará por alimentar, levar, sobretudo, à reflexão sobre os jogos amorosos e libertinos, sobre a virtude e a inconstância, a felicidade e a ilusão, o ideal e o real. Temas sérios e dignos da maior atenção por parte dos moralistas, mas que são aqui discutidos em tom jocoso num diálogo de sedução, onde a protagonista se vai deixando levar a pouco e pouco pelos argumentos de uma voz que ela julga ouvir, ou que the fala num sonho ou que pode muito bem não passar da voz íntima do seu próprio desejo, atacado por todos os lados pelo novo modelo

\footnotetext{
${ }^{7}$ Cf. Bessière (1974: 13).
} 
amoroso da libertinagem galante. Com efeito, florescente no seio da sociedade aristocrática francesa, tal modelo representa uma transformação profunda operada na hierarquia dos valores deste microcosmo social, passando o código da galanteria a sobrepor-se ao código terno e precioso que vigorara no decurso do século XVII.

Elemento imaginário cabalista, génio composto pelos mais puros átomos de ar, o Silfo de Crébillon evoca, no espírito do leitor seu contemporâneo, certas qualidades, como a juventude, a audácia, a graça e a delicadeza, que caracterizam o novo ideal de amante nascido do código da nova "Arte do Gosto". A leitura do texto confirmará tais expectativas, visto que este génio aéreo e invisível aí se afirma omnisciente em relação aos mais secretos desejos e pensamentos das mulheres. Com efeito, a personagem do Silfo esconde-se na invisibilidade de uma voz tentadora e persuasiva, sendo só perto do final que este espírito fascinante toma forma visível e palpável no corpo do mais belo homem que se possa imaginar, aparição ofuscante que completa a sedução da jovem Condessa (justamente o oposto às aventuras de Alvare e Alphonse, protagonistas, respectivamente, de Cazotte e Potocki).

O texto da carta inicia-se com um "preâmbulo", no qual a epistológrafa tenta estabelecer a sua autoridade e credibilidade, ao mesmo tempo que procura preparar cuidadosamente a descrença da amiga, espelho do leitor da obra, cuja credulidade e benevolência devem ser conquistadas, de igual forma, pela instância autoral. Num segundo momento, para contextualizar a aventura que vai narrar em seguida, Mme de $R^{\star * \star}$ tece um elaborado discurso, distanciando-se dos valores e do turbilhão dos costumes mundanos coevos e afirmando categoricamente a sua divergência tanto em relação à sua interlocutora epistolar como à alta sociedade parisiense em geral. Essa diferença consiste na sua inequívoca preferência pela tranquilidade campestre, pois se Paris é o símbolo do microcosmo galante da Regência, sendo apresentado pela epistológrafa como o lugar da frivolidade, do ridículo, da maledicência e da libertinagem, por contraponto, o campo é, na sua opinião, o lugar propiciador de uma agradável solidão, da reflexão e, acima de tudo, do "songe" (sonho ou devaneio imaginativo) portador de felicidade, ainda que ilusória.

Aparentemente, segundo Mme de $\mathrm{R}^{\star \star *}$, uma tal diferença de gostos e de modo de pensar ter-Ihe-á sido favorável, pois a sua solidão revela-se antes cheia de prazeres, ainda que possam ser irreais. Ela dá-os como sonhos, mas infinitamente mais agradáveis do que os prazeres mundanos. Aguçando a curiosidade da sua destinatária, a Condessa procura justificar-se, mas também captar a benevolência da amiga relativamente aos argumentos apresentados, preparando, assim, o terreno para explicitar o seu desejo antigo de ser digna do amor de um silfo. Afinal, é este desejo que a leva a procurar o refúgio da solidão campestre e a recusar severamente qualquer ligação galante (pelo menos, ela assim o afirma). A estratégia desta conduta revela-se finalmente eficaz com a produção do sonho (?) 
do colóquio com um silfo sedutor, encontro amoroso esse que, apesar de falhado, ela se apressa a narrar por escrito à sua confidente:

C'est un songe, je ne vous donnerai mon aventure que sur ce pied-là, il faut ménager votre incrédulité. Cependant, si c'était un songe, je me souviendrais de m'être endormie avant que de l'avoir commencé: j'aurais senti mon réveil, et puis quelle apparence qu'un songe eût autant de suite qu'il y en a dans ce que je vais vous raconter! comment aurais-je si bien retenu les discours du Sylphe? II n'est pas naturel que j'aie pensé ce que vous allez entendre, toutes les idées que vous y trouverez ne m'ont jamais été familières. Oh, assurément! Je n'ai pas rêvé, vous en croirez au reste ce qu'il vous plaira; quand à moi, je ne me servirai pas de ces mots, il me semblait, je croyais voir; je dirai, j'étais, je voyais, mais finissons ce préambule. (Crébillon, 1999: 24)

Aqui é muito evidente quer o jogo ambíguo entre sonho e realidade, quer o jogo com a inverosimilhança da hipótese onírica, remetendo-se a responsabilidade da decisão interpretativa para a instância receptora - a destinatária intradiegética e o leitor da obra. Apesar de se ter tratado apenas de um encontro fugaz (uma só noite), incompleto e, provavelmente, ilusório, não deixa de ser interessante notarmos que ele deixou a marca de um agradável prazer reavivado pela escrita da carta-relato (ao contrário do que vai suceder com o Marquês do conto de Maupassant). Com efeito, o Silfo revelou-se um sedutor fora do comum, um ser de eleição correspondente ao amante ideal da Condessa. "Oh, assurément! Je n'ai pas rêvé" é uma denegação que acentua a ambiguização ulterior, contribuindo para a construção da indecidibilidade do sentido, marca, por um lado, da poética crébilloniana, mas, por outro, prenunciadora da narrativa fantástica. Com o seu preâmbulo, a redactora afirma, pois, a superioridade dos prazeres da imaginação sobre os prazeres do hábito, do amor impossivelmente absoluto sobre a galanteria. No entanto, a sua fácil adesão ao sistema hedonista do libertino coloca este aspecto em questão, permitindo a suspeita de que aquilo que se recusa é o conquistador ridículo e de pouca importância, desejando-se, porém, ser digna das atenções de um verdadeiro mestre na arte da sedução.

Terminado o preâmbulo preparatório do espírito da sua interlocutora, a epistológrafa inicia a narrativa da sua aventura nocturna (onírica ou não), contextualizando-a através da descrição do cenário onde esta se desenrola. A cena é interessante: por uma cálida noite de Verão, no campo (onde, todavia, as obrigações sociais também são obsidiantes), refugiada na solidão tranquila do seu quarto, a jovem Condessa encontra-se deitada "d'une façon modeste, pour quelqu'un qui se croit seul, mais qui ne l'aurait pas été si j'eusse cru avoir des spectateurs" (24-25). E que faz ela? Lê um livro de moral... Inesperadamente, a sua beleza assim exposta provoca uma exclamação proferida, "à demi-bas et avec un soupir" (25), por 
uma voz invisível e extasiada, que denuncia a presença clandestina de um espectador masculino: "Ô Dieu, que d'appas!" (25). Ora, o desnudamento da narradora, verosimilmente justificado pelo calor da noite estival e pelo facto de ela se julgar sozinha na intimidade do seu quarto, contrasta, no entanto, com o conteúdo da sua leitura. Assim, logo a partir da cena inicial, o texto instaura a ambiguidade quanto às verdadeiras intenções da protagonista, uma vez que o seu estado imodesto pode ser interpretado como uma atitude de expectativa, mesmo que inconsciente, pois ela confessou, no preâmbulo da carta, ter sempre ardentemente desejado ser digna do amor de um silfo e procurar a solidão campestre tão-só na esperança de uma manifestação de um destes génios invisíveis, espíritos elementares habitantes do ar, o que parece ter finalmente ocorrido - e no contexto dos alvores das Luzes!

Surpreendida e apavorada com esta voz masculina que insiste em elogiar os seus atractivos, Mme de $\mathrm{R}^{\star * \star}$ procura refúgio sob o lençol, o que provoca um queixume de desespero apaixonado da parte do seu admirador invisível, provavelmente o silfo anunciado no título. Deste modo, ele irrompe na narrativa como uma voz que, vendo sem ser visto à maneira de um voyeur, se declara extasiado com os encantos físicos da Condessa, desesperando-se quando esta Ihos oculta. Profundo conhecedor da arte da sedução libertina, ele está, deste modo, a dar início à sua estratégia de conquista: em primeiro lugar, procura captar a atenção e a benevolência da mulher, despertando a sua vaidade com os elogios à sua superior beleza, indigna de um mortal. Com esta expressão sugere-se que a voz não pertencerá ao plano do humano. Em seguida, a leve sugestão do desejo de posse torna-se mais explícita, embora velada ainda sob o jargão amoroso precioso: a cruel que desespera um amante respeitoso e que a adora. Segue-se o diálogo de sedução, em que, tanto lisonjeada como curiosa, a Condessa começa lentamente a vencer o medo e a surpresa, minando assim a resistência aos avanços do sedutor. Seguro da sua estratégia, o génio reitera uma declaração de amor polida e respeitosa com o intuito de tranquilizar a vítima.

A narradora, porém, afirma debater-se num turbilhão de ideias contraditórias, crendo, por um lado, nada dever temer desta aventura insólita e tentadora, mas, por outro, receando uma atitude violenta e atentatória da sua virtude por parte desta entidade que se diz apaixonada por si, e que ela imagina ser um espírito mais forte do que qualquer homem. Tranquilizando-a, ele mostra-se respeitoso e submisso relativamente aos desejos dela. $\mathrm{A}$ sedução opera aqui através do poder persuasivo das palavras e dos argumentos falaciosos utilizados pelo Silfo e não pela violência da força física. O objectivo do Silfo é, então, obter o consentimento da vítima na sua própria derrota, convencê-la para vencê-la, isto é, convertêla ao culto da volúpia ou levá-la a reconhecer que é esse o seu desejo secreto, apesar de ela procurar contrapor-Ihe os argumentos do sistema da virtude. Segundo ele, porém, a 
virtude é unicamente numa máscara que esconde o desejo, um ideal fora de moda, enquanto o prazer se mostra bem real e vivo. Se a verdadeira virtude é uma quimera e se a hipocrisia é condenável, então, o único caminho que resta é o da aceitação da "filosofia moderna" do hedonismo e do culto da volúpia - tipo de discurso passível de ser atribuído ao Diabo, independentemente da forma que decida assumir (cf. Muchembled, 2003).

Mais adiante, a voz do Silfo libertino transforma-se numa voz narradora autodiegética $^{8}$, que começa a contar uma parte das suas múltiplas e variadas aventuras amorosas. Esta narração permite-lhe demonstrar que a sua ciência da sedução se encontra, efectivamente, baseada na observação e na experimentação, sendo, portanto, de natureza teórico-prática. Tal forma de pensamento, embora procure ir ao encontro do espírito racionalista da época, contrasta ironicamente - e nesta ironia aflora a problematização do género do conto maravilhoso por parte da instância autoral - com a possível natureza maravilhosa da personagem narradora. Não obstante, a narrativa das conquistas amorosas do Silfo reforça a sua autoridade na matéria e constitui um meio táctico ao serviço da sua presente estratégia de sedução, uma vez que, por um lado, provoca na sua interlocutora a sugestão do desejo imaginado e, por outro, dá-lhe a garantia de que, não sendo ela diferente de todas as outras mulheres, sucumbirá fatalmente, mas estando desculpabilizada logo à partida.

O Silfo libertino, que já se revelou um verdadeiro mestre nos domínios da teoria e da prática do jogo da sedução, efectua, em seguida, uma manobra táctica decisiva para quebrar a resistência da sua interlocutora, ao fingir desistir da sua conquista, simulando a derrota e a partida. Tal atitude constitui um modo de se assegurar da vitória final, visto que contribui para consolidar a confiança da estratégia perdedora de Mme de $R^{\star * \star}$. Com efeito, não escondendo a sua desilusão, esta tenta retê-lo um pouco mais e admite, enfim, a sua curiosidade, abrindo uma brecha na sua resistência: "Comment voulez-vous que je vous aime! Sais-je seulement ce que vous êtes!" (31). Embora o desejo feminino se manifeste veladamente, o libertino não desperdiça o belo efeito proporcionado pela táctica anterior, continuando, por um lado, a aguçar-Ihe a curiosidade e, por outro, obrigando-a a reiterar a questão e a confessar o desejo, perguntando-Ihe: "Vous [...], qui croyez-vous que je sois?" (32). A resposta do desejo da Condessa é evasiva: "Je vous crois [...] Esprit, Démon, ou Magicien. Mais sous quelque espèce que je vous imagine, je vous crois quelque chose de fort aimable et de fort singulier" (32). Ou seja, uma das provas de que a sedução já foi bem sucedida, sendo a sua conclusão apenas uma questão de tempo, é o facto de a Condessa

\footnotetext{
${ }^{8}$ Muito ao gosto da estruturação por encaixe de sucessivas narrativas, da responsabilidade de diferentes narradores, característica do conto maravilhoso oriental segundo o modelo das Mil e Uma Noites, obra, como é sabido, de grande sucesso em França a partir da primeira década de Setecentos, com a tradução-adaptação de Antoine Galland.
} 
já não revelar medo da entidade supostamente sobrenatural. Não obstante, a dama recusa, por enquanto, autorizar a corporalização da voz.

Por fim, o Silfo revela a sua verdadeira natureza, provocando o êxtase da interlocutora, o que corresponde à assunção do desejo por parte desta. Ora, isso acaba por funcionar como uma "declaração de amor" equivalente à do Silfo. Para completar o processo de sedução da Condessa, o libertino apenas necessita de "obter as provas". Num primeiro momento, ela recusa; o diálogo prossegue, tornando progressivamente as condições mais suaves e, portanto, mais tentadoras. Ela tem agora a possibilidade e a responsabilidade de decidir a sua própria rendição. Resta saber até que ponto se trata de uma decisão que possa racionalmente ser tomada em consciência e não sob o efeito do fascínio do momento. Seduzida pela palavra e pelo sistema do libertino, o último refúgio da Condessa consiste em não lhe permitir que tome corpo. Porém, ele interpreta essa resistência no sentido contrário e mostra-se, enfim, com todo o seu esplendor. Imediatamente, representando o papel de amante terno e respeitoso, o sedutor lança-se aos joelhos da Condessa, obtendo a pretendida confissão do seu amor e quase conseguindo a prova física. Porém, esta é, infelizmente, uma ocasião perdida, uma vez que os amantes são subitamente surpreendidos pela inesperada irrupção no quarto da criada da Condessa, o que provoca o desaparecimento do espírito - ou o desfazer da ilusão, ou o acordar do sonho... Mme de $\mathrm{R}^{\star \star \star}$ chama insistentemente pelo seu amado Silfo, mas é em vão. Uma tal indiferença leva-a a considerar a hipótese de tudo não ter passado de "une agréable illusion qui s'est présentée à [son] esprit" (37). Decide, então, escrever imediatamente uma carta à sua confidente, onde lhe conta a sua aventura nocturna extra-ordinária.

"Agréable illusion" é uma expressão que caracteriza os eventos narrados nesta epístola como ilusórios, quer a sua protagonista os tivesse sonhado durante o sono, quer os tivesse imaginado e vivido, acordada, como um devaneio ou uma fantasia. Não obstante, eles foram sentidos como agradáveis, ou seja, como uma aventura de prazer. A epistológrafa termina a sua carta de modo bastante significativo, deixando no ar uma pergunta, que tanto pode ser dirigida a si própria como à sua correspondente (e, naturalmente, a instância autoral estende-a também ao seu leitor): "mais n'est-il pas dommage que ce ne soit qu'un songe?" (37). Esta abertura final (pois uma pergunta, mesmo retórica, pressupõe uma resposta) reforça a ambiguidade do sentido da obra, reconduzindo ao seu início: afinal, o que é que sucedeu à Condessa, que the deu tanto prazer que ela logo resolveu contar à amiga? Teria sido um encontro com um elemento sobrenatural, um sonho inconsciente, uma fantasia erótica ou mesmo um acontecimento real ocultado pela aparente narrativa maravilhosa? Sendo aquelas as palavras finais do texto, elas assumem, pois, uma importância extremamente significativa a vários níveis. No plano intradiegético, a autora da carta parece terminar, insistindo na ambiguidade da natureza do sedutor e dos eventos 
narrados, deixando, assim, à sua destinatária a liberdade de decidir como interpretá-los. Visto que a história se situa no início do século XVIII francês, é perfeitamente verosímil que as duas senhoras possam hesitar entre uma explicação racional, mais no espírito cartesiano, ou a aceitação pura e simples do sobrenatural.

O mesmo poderá ser dito relativamente ao público leitor do tempo, sobretudo, o feminino. Com efeito, à época, cruzam-se, como sabemos, as influências da moda dos contos maravilhosos (de fadas ou influenciados pelas Mil e Uma Noites, fontes tanto de fascínio como de educação, nomeadamente, moral) e o racionalismo das Luzes. Assim, no plano extradiegético, a instância autoral faz-se igualmente ouvir nas palavras finais do texto, colocadas na pena da sua personagem fictícia, dirigidas agora a todo o tipo de leitores, crédulos ou incrédulos, tanto os coevos como os das gerações subsequentes. À questão relativa à ambiguidade entre sonho e realidade - sendo que, paradoxalmente, a primeira hipótese seria a racionalmente verosímil e a segunda a da ordem do maravilhoso - vêm juntar-se outras tantas, essas bem crébillonianas: desejo e sentimento amoroso serão conciliáveis ou tal união é uma pura quimera? O desejo é passível de ser satisfeito plenamente ou a sua verdadeira natureza é a falta e a incompletude? Em nosso entender, são já estas as questões que aqui preocupam verdadeiramente Crébillon ${ }^{9}$. A forma complexa e o motivo esotérico escolhidos para este seu primeiro texto evidenciam, sobretudo, uma percepção atenta e irónica da mentalidade e dos gostos estético-literários dos seus contemporâneos. Estamos, assim, perante um objecto de transição entre o conto maravilhoso, cuja moral é tranquilizadora - mesmo no caso do Capuchinho Vermelho que, na versão de Perrault, alerta, sobretudo, as jovens para o perigo de darem ouvidos aos predadores de falinhas mansas -, e a narrativa fantástica provocadora de intranquilidade pela hesitação em que deixa o leitor face às certezas racionais que patilha com a doxa.

Será justamente no final do século XVIII que os encontros amorosos com entidades hipoteticamente sobrenaturais - por exemplo nos casos tanto de Alvare como de Alphonse, protagonistas respectivamente de Le Diable amoureux e de Manuscrit trouvé à Saragossese pautarão por um misto de êxtase dos sentidos e de verdadeiro terror, ao contrário da jovem Condessa de Crébillon, primeiro assustada e depois agradavelmente seduzida com a visita de uma criatura sobrenatural. Incapazes de resistir à sedução feminina, os dois heróis vêem-se a braços com o pavor de perderem as suas almas para o Diabo. Deste modo, a associação da figura do Diabo ao desejo erótico, nomeadamente representado através de belas jovens tentadoras, reaparece no imaginário literário francês após o apogeu das Luzes e da libertinagem galante da sociedade da Regência e do reinado de Luís XV. Em Cazotte, a ambiguidade estrutural encontra-se associada, de forma inovadora, ao facto de se

\footnotetext{
${ }^{9}$ A resposta a estas questões não se encontra neste texto inaugural de Claude Crébillon, mas elas serão retomadas, sob múltiplas formas, em todas as suas obras posteriores.
} 
encenar a atracção pelo Mal, inerente à alma humana. Ou seja, o princípio da queda da humanidade parece estar na ânsia de liberdade. Assim, Alvare arrisca-se ao Inferno por possuir um espírito, mais do que curioso pelas ciências ocultas, de revolta, acentuada pelo orgulho $^{10}$. Tal como em Cazotte, também em Potocki a situação do jovem protagonista (e narrador) oscila entre a inverosimilhança da hipótese sobrenatural, que o cepticismo da razão não the permite aceitar facilmente, e a incapacidade de, paradoxalmente, explicar verosimilmente os fenómenos impossíveis que aparentemente lhe sucederam ${ }^{11}$. Não será certamente coincidência o facto de, em ambas as narrativas, a acção se situar num contexto cultural espanhol, onde a força dos preceitos e superstições católicos é bem mais forte do que no da França coeva. Deste modo, permite-se tanto o jogo verosímil com a (in)credulidade do leitor como uma maior pluralidade interpretativa.

Em pleno século XIX, também Baudelaire explora, a seu modo, o jogo verosímil com a (in)credulidade do leitor perante o sobrenatural, nomeadamente face à figura do Diabo. Deixemos de lado a colectânea Les Fleurs du Mal, pois a leitura poética, segundo Todorov, mata o fantástico (Todorov, 1977: 57). Concentremo-nos antes nas seguintes palavras de Louis Vax: "Tradutor de Edgar Poe, muitas vezes inspirado em Les Fleurs du Mal pelo

\footnotetext{
${ }^{10}$ Iniciado na cabala, Alvare, um jovem nobre espanhol - e o narrador autodiegético do texto -, invoca o Diabo nas ruínas de Portici. Subitamente, uma fantástica cabeça de camelo irrompe na parede da gruta, vociferando "Che vuoi?". Controlando a sua perplexidade e o seu medo, Alvare experimenta o seu poder sobre essa criatura monstruosa: ordena-lhe que se metamorfoseie em fraldiqueiro, depois em pajem - que se coloca devotadamente ao seu serviço e tudo faz para o seduzir. É que, se o animal é, afinal, uma cadelinha, o pajem é um ser de tão admirável e encantadora beleza que surge a ambiguidade quanto ao seu sexo - rapaz ou rapariga? Biondetto/Biondetta possui ainda o charme do talento musical e, ao longo da narrativa, revela-se enigmática, tanto tirânica como submissa, caprichosa como fiel, provocante como esquiva. Após uma forte resistência aos seus perturbadores encantos, Alvare torna-se seu amante. Nesse momento, Biondetta convida-o a chamá-la pelo seu verdadeiro nome e a murmurar "Mon cher Belzébuth, je t'adore". Perante a hesitação de Alvare, ela revela a sua verdadeira natureza diabólica, no meio de um aterrador clarão provocado por fantásticos caracóis fosforescentes, retoma a sua forma monstruosa e desaparece quando o jovem apavorado se esconde debaixo da cama e quase perde os sentidos. Será trazido de novo à realidade (?) pelo caseiro que afirma que Alvare dormiu catorze horas e que a jovem senhora partira logo cedo e aguardaria por ele na aldeia mais próxima. Naturalmente, Alvare não sabe o que pensar da sua aventura nocturna. De novo em casa da mãe, apercebe-se de que viveu um longo período com Biondetta - o Diabo (?). Porém, de volta à realidade da razão não sabe bem que credibilidade conferir às suas aventuras e se tudo não terá passado, afinal, de um pavoroso pesadelo. A ambiguidade permanece no final da narrativa, aspecto que faz dela a inauguradora de um novo género fundado na temática do sobrenatural maléfico.

${ }^{11}$ Pelo menos quanto à estrutura inicial da narrativa, que instaura e mantém até perto do final a ambiguidade quanto a uma explicação racional ou à aceitação dos fenómenos meta-empíricos como manifestações diabólicas. A completa perplexidade de Alphonse perante os acontecimentos leva-o a confessar a sua incapacidade de emitir uma opinião segura acerca das duas belas irmãs que se dizem suas primas e com quem acaba por ter alguns encontros insólitos ("Je ne savais plus si j'étais avec des femmes ou bien avec d'insidieux succubes", Potocki, 2002: 65). Por vezes, inclina-se para a aceitação da explicação pelo sobrenatural - dada por outras personagens: "Mais, seigneur Alphonse, reprit Rébecca, comment pouvez-vous imaginer qu'une parole d'honneur donnée à deux démons puisse vous engager? Or nous savons que ce sont deux démons femelles et que leurs noms sont Émina et Zibeddé" (188); ou suscitada pela ilusão da sua própria percepção: "Ceci me parut ressembler si fort à une insinuation de Satan que je croyais déjà voir des cornes sur le joli front de Zibeddé" (70). No entanto, quando crê que elas são humanas, a perplexidade instala-se no seu espírito: "'Oh! ciel! Me dis-je en moi-même, serait-il possible que ces deux être si aimables et si aimants ne fussent que des esprits lutins, accoutumés à se jouer des mortels en prenant toutes sortes de formes, des sorcières peut-être, ou, ce qu'il y aurait de plus exécrable, des vampires à qui le ciel aurait permis d'animer les corps hideux des pendus de la vallée?' II me semblait bien que tout ceci pouvait s'expliquer naturellement, mais maintenant je ne sais plus qu'en croire" (193). O final resolve aparentemente pela via da racionalização, mas a inverosimilhança desta explicação não acaba com a ambiguidade anteriormente instalada.
} 
horrível e pelo macabro, Charles Baudelaire [...] criou nos Petits Poèmes en Prose [1869] um género original, parente do conto fantástico propriamente dito" (Vax, 1972: 151). De facto, estes poemas em prosa, partilhando, é certo, da plasticidade da linguagem poética, constituem pequenas ficções, possibilitando a aproximação referida por Vax. Le Spleen de Paris, título efectivo da colectânea, tem Paris por tema, mas também como enquadramento geográfico e temporal, ou seja, o que é realçado é o presente quotidiano, a modernidade da era industrial, capitalista e positivista, onde não seria muito evidente a presença de entidades da ordem do meta-empírico. Não obstante, surgem, em Le Spleen de Paris, várias criaturas sobrenaturais como quimeras, fadas, gnomos, salamandras, sílfides e silfos, a antropomorfização da morte, divindades sem auréola, etc.. Contudo, a todas elas, sobrepõese a dúplice figura do Diabo.

Este apresenta-se como uma figura ambígua, oscilando entre a representação do pecado e da miséria, por um lado, e uma possibilidade de salvação, por outro. Baudelaire explora algo a que poderíamos chamar um satanismo moderno, pois embora utilize o imaginário romântico, fá-lo significar outra coisa. A questão da dicotomia Bem/Mal, presente constantemente, vai assumir diferentes aspectos. Trata-se, antes de mais, do problema cristão do Pecado e da Redenção. E já aqui surge a ambiguidade: o sujeito enunciador sente um grande desejo de Deus (Ideal e Harmonia, Espiritualidade e Belo), mas esse desejo é contrariado pela sua condição humana, que o faz mergulhar num mundo degradado ao assalto das Tentações. Ele descobre que o verdadeiro Mal é o Ennui da vida urbana moderna, esse universo caótico onde reinam a idiotice, a degradação progressiva, o tumulto, a devassidão, os contrastes gritantes, o positivismo, as revoluções políticas falhadas. Perante tal espectáculo, esta voz revolta-se contra Deus e escolhe a saída pelo Mal, exaltando a transgressão. É então que o Diabo aparece como "irmão" ou, como Baudelaire escreve no Epílogo, "patron de ma détresse". Também ele é um transgressor e um vencido, surgindo, simultanea e paradoxalmente, como o Mal e a possibilidade de salvação.

Os poemas mais emblemáticos do que acabamos de dizer são três: "La chambre double", "Les tentations, ou Éros, Plutus et la Gloire" e "Le joueur généreux". No primeiro, onde a duplicidade está já patente no título, assistimos à irrupção súbita e inexplicável do real caótico (sobrenatural?) na harmonia do Ideal. Tal ambiguidade contamina o espaço fechado do quarto, que, de espaço do sonho de Ideal, se metamorfoseia num ambiente sujo, frio, escuro, triste, caótico, fétido e desolador, marcado por datas sinistras e trabalho não efectuado, devido à perturbação provocada por um espectro diabólico que bate à porta e traz consigo todo o tédio da vida real. Neste contexto de desolação, destaca-se um objecto paradoxalmente libertador: "Dans ce monde étroit, mais si plein de dégoût, un seul objet connu me sourit: la fiole de laudanum; une vieille et terrible amie; comme toutes les amies, 
hélas! féconde en caresses et en traîtrises" (Baudelaire, 1972: 35-36). Mas a ambiguidade contamina também o sujeito humano e o próprio real. Reina de novo o Tempo, esse "hideux vieillard", com o seu "démoniaque cortège de Souvenirs, de Regrets, de Spasmes, de Peurs, d'Angoisses, de Cauchemars, de Colères et de Nevroses" (36), terminologia do sobrenatural que designa aqui, paradoxalmente, o real. A "insupportable" e "implacable Vie" surge como condenação, Inferno de maldição, ao qual é preciso escapar, através dos "paraísos artificiais" ou da Morte (36). Uma curiosa alteração verifica-se, porém, neste poema: não é a iluminada e lisa parede do real que abre uma fenda para o sobrenatural inquietante, como dizia Todorov. Há aqui, de facto, uma ruptura numa experiência vivida, mas essa "experiência" é o Ideal, e o elemento que produz a irrupção escandalosa e evidente é o real alterado. O escândalo, a transgressão da lei encontra-se nesta colagem paradoxal. Assim, repudia-se o infernal tédio do quotidiano em nome de uma paradisíaca felicidade sonhada.

No segundo poema acima referido, "Les tentations, ou Éros, Plutus et la Gloire", o Diabo encarna a ambiguidade divino/satânico e o sujeito enunciador, também de modo ambíguo, oscila entre a recusa e o desejo do Mal. O imaginário cristão apresenta-se aqui misturado com a mitologia greco-latina, contribuindo para a contaminação divino/satânico nestas três figuras que lembram uma imagem deformada da Santíssima Trindade, tentações do demónio sob a forma humana: "Deux superbes Satans et une Diablesse, non moins extraordinaire" (84). Trata-se de um inferno imaginário, inconsciente, do plano do onírico ("[ils] ont la nuit dernière monté l'escalier mystérieux par où l'Enfer donne assaut à la faiblesse de l'homme qui dort et communique en secret avec lui", p. 84). As três tentações aludidas neste poema (erotismo, cupidez e a fama) revelam-se, tal como os "paraísos artificiais", ineficazes para escapar ao "Ennui" maldito da condição humana e artística através da escolha do Mal. Aqui, a ambiguidade fantástica joga-se entre o Bem e o Mal, por um lado, e por outro, na inversão paradoxal da caracterização do real e do sobrenatural: o primeiro surge como bizarro, perturbador e angustiante, enquanto o segundo se mostra sedutor e desejável. As três tentações, tidas como satânicas, estão, afinal, na vida quotidiana e no próprio coração humano, pois, para além de elas assumirem figuras antropomórficas, estabelece-se igualmente a sua comparação com elementos simbólicos do plano do real, caracterizado como degradado, desumano e spleenático, do qual, por consequência, o sujeito da enunciação deseja evadir-se, mesmo que seja necessário escolher o Mal.

Finalmente, o terceiro poema referido, "Le joueur généreux", apresenta-nos a personagem do Diabo como imagem de fraternidade, de possibilidade de salvação do Ennui, evidenciando a dupla postulação Deus/Satanás. Surge, de novo, a ambiguidade, primeiro no título, onde se verifica a contaminação humano/satânico (o jogador) e a contaminação divino/satânico (a generosidade que supostamente o caracteriza). Depois, ela 
reaparece na irrupção do sobrenatural no real, quando uma entidade misteriosa aborda discretamente o sujeito enunciador numa rua parisiense, no meio da multidão:

Hier, à travers la foule du boulevard, je me suis senti frôlé par un Être mystérieux que j'avais toujours désiré connaître, et que je reconnus tout de suite, quoique je ne l'eusse jamais vu. II avait sans doute chez lui, relativement à moi, un désir analogue, car il me fit, en passant, un clignement d'oeil significatif auquel je me hâtai d'obéir. (Baudelaire, 1972: 114)

Tal gesto sugere cumplicidade e sedução, por parte do ser misterioso, e despoleta a obediência do seu destinatário, uma vez que o sujeito enunciador o segue voluntariamente, como se se tratasse de uma descida ao Inferno, ao desconhecido, levado pela sua curiosidade. Deste modo, abre-se uma fenda no real quotidiano e familiar, despercebida aos olhos dos outros não iniciados ${ }^{12}$. Este lugar, à semelhança de "La Chambre double", apresenta claras afinidades com o ldeal ambicionado e os outros aí residentes, as almasgémeas que reflectem o espírito do sujeito da enunciação, abominam o Ennui. Uma vez mais, verifica-se a ambiguidade e a contaminação entre divino/ldeal e satânico, pois este espaço, caracterizado com traços paradisíacos, refere-se, paradoxalmente, ao local habitado pelo Diabo, logo, ao Inferno. Por outro lado, também o anfitrião se vai excedendo em iguarias requintadas e gentilezas, de tal modo que o sujeito enunciador se considera já tratado como se fossem "de vieux et parfaits amis": "Nous mangeâmes, nous bûmes outre mesure de toutes sortes de vins extraordinaires, et, chose non moins extraordinaire, il me semblait, après plusieurs heures, que je n'était pas plus ivre que lui"' (Baudelaire, 1972: 115).

Trata-se, afinal, de uma subtil estratégia de sedução por parte do ser misterioso, que conduz o hóspede de forma a ganhar-Ihe a alma ao jogo: "Cependant le jeu, ce plaisir surhumain, avait coupé à divers intervalles nos fréquentes libations, et je doit dire que j'avais joué et perdu mon âme, en partie liée, avec une insouciance et une légèreté héroïques" (115). O jogo, esse "plaisir surhumain" movido pelas regras e pelo acaso (perder ou ganhar), seduz e perde o sujeito enunciador. A mestria do jogador adversário é tal que o perdedor pouca importância presta ao objecto perdido, a sua própria alma, e, ao contrário de Fausto, sem sequer ter recebido nada em troca. Não se trata aqui, com efeito, de vender a alma ao Diabo na mira de se alcançar algo muito desejado, mas tão-só de apostá-la gratuita e displicentemente ao jogo, pois, como afirma o sujeito da enunciação, "l'âme est une chose si impalpable, si souvent inutile et quelquefois si gênante, que je n'éprouvai, quant à cette perte, qu'un peu moins d'émotion que si j'avais égaré, dans une promenade, ma carte de visite" (115-116).

\footnotetext{
${ }^{12}$ Cf. Baudelaire (1972: 114-115).
} 
O tom trocado entre ambos torna-se, pouco a pouco, no de uma certa familiaridade, pois, apesar do tratamento do suposto Demónio por "Son Altesse" mais adiante na conversa sobre a criação e a futura destruição do Universo, ele é desde já o "vieux Bouc!" (116). O colóquio aborda, então, vários temas interessantes: "l'univers, sa création et sa future destruction", "la grande idée du siècle", ou seja, "[le] progrès et la perfectibilité", e ainda "toutes les formes de l'infatuation humaine" (116-117). O sujeito da enunciação, "encouragé par tant de bontés", aproveita, ainda, para pedir "des nouvelles de Dieu" a este "étrange convive" e saber "s'il l'avait vu récemment", ao que o outro responde: "Nous nous saluons quand nous nous rencontrons, mais comme deux vieux gentilshommes, en qui une politesse innée ne saurait éteindre tout à fait le souvenir d'anciennes rancunes" (117). Tal referência acentua, com subtileza, a dicotomia divino/satânico, bem como o modo de caracterização do plano do sobrenatural através de marcas do plano do humano, tornando o primeiro quase tão familiar como o último, ou seja, problematizando o próprio conceito de fantástico.

No entanto, continua a verificar-se uma natural submissão do sujeito enunciador, simples mortal, ao suposto Príncipe das Trevas ("Il est douteux que son Altesse ait jamais donné une si longue audience à un simple mortel, et je craignais d'abuser"). Contudo, "ce célèbre personnage, chanté par tant de poètes et servi par tant de philosophes qui travaillent à sa gloire sans le savoir", decide, surpreendentemente, recompensar a sua submissão: "Enfin, comme l'aube frissonnante blanchissait les vitres [il] me dit: 'Je veux que vous gardiez de moi un bon souvenir, et vous prouver que Moi, dont on dit tant de mal, je suis quelquefois bon diable, pour me servir d'une de vos locutions vulgaires" (117-118). Assim, este ser célebre, uma vez mais com grande subtileza e mestria, procura seduzir o seu interlocutor mortal com uma proposta tentadora e até mesmo irrecusável ${ }^{13}$. A perda irremediável da alma seria, então, compensada pela possibilidade total e vitalícia de vencer o tédio, realizando todos os anseios pessoais, reinando sobre a Humanidade, tornando-se num objecto de bajulação e adoração e podendo, naturalmente, obter ainda riqueza e prazer sem limites nem esforço. A estratégia do sedutor parece, de facto, produzir o efeito desejado e sair vencedora, de acordo com a confissão do próprio sujeito da enunciação: "Si ce n'eût été la crainte de l'humilier devant une aussi grande assemblée, je serais volontiers tombé aux pieds de ce joueur généreux pour le remercier de son inouïe munificence" (118-119).

\footnotetext{
${ }^{13}$ Cf.: "'Afin de compenser la perte irrémédiable que vous avez faite de votre âme, je vous donne l'enjeu que vous auriez gagné si le sort avait été pour vous, c'est-à-dire la possibilité de soulager et de vaincre, pendant toute votre vie, cette bizarre affection de l'Ennui, qui est la source de toutes vos maladies et de tous vos misérables progrès. Jamais un désir ne sera formé par vous, que je ne vous aide à le réaliser; vous régnerez sur vos vulgaires semblables; vous serez fourni de flatteries et même d'adorations; l'argent, l'or, les diamants, les palais féeriques, viendront vous chercher et vous prieront de les accepter, sans que vous ayez fait un effort pour les gagner; vous changerez de patrie et de contrée aussi souvent que votre fantaisie vous l'ordonnera; vous vous soûlerez de voluptés, sans lassitude, dans des pays charmants où il fait toujours chaud et où les femmes sentent aussi bon que les fleurs, - et cætera, et cætera...', ajouta-t-il en se levant et en me congédiant avec un bon sourire" (Baudelaire, 1972: 118).
} 
Contudo, quando começa a subtrair-se lentamente ao domínio encantatório da sedutora criatura, tal "prodigieux bonheur" desperta a habitual desconfiança do sujeito enunciador (119). Curiosamente, esta desconfiança não revela um repúdio pela oferta do jogador generoso, mas talvez demoníaco. Muito pelo contrário, o que se receia é a quebra da promessa daquele, sendo o sujeito enunciador levado, enquanto faz as suas preces nocturnas, "par un reste d'habitude imbécile", a proferir as seguintes palavras: "Mon Dieu! Seigneur, mon Dieu! faites que le diable me tienne sa parole!'” (119). Supremo paradoxo, ou mesmo blasfémia, que acentua a contaminação divino/satânico e a inversão do escândalo fantástico, pois o elemento perturbador, o símbolo absoluto do mal da humanidade, é aqui visto como algo benéfico e desejável.

Em Le Spleen de Paris, a justaposição, sem ligação interna, dos vários quadros, que se reflectem ou contradizem, tem, em primeiro lugar, um efeito de jogo de contrastes, para o qual concorre, por exemplo, a alternância de poemas satânicos e outros moralizadores ou fraternos. Todavia, por outro lado, essa justaposição permite também reproduzir um universo caótico, ele próprio feito de contrastes profundos, de degradação e de choque, isto é, a vida na grande capital moderna. Neste contexto, os elementos sobrenaturais contribuem para esse fim comum de recusa do Ennui e desejo do Ideal, operando por via da ênfase no jogo de transgressões, quer dizer, na tentativa de encontrar o Ideal através do Mal como revolta. E, neste aspecto, Baudelaire filia-se numa certa admiração romântica pelo Príncipe das Trevas, visto como Anjo revoltado. No entanto, encontramos nesta colectânea, e paradoxalmente em relação aos espíritos das Luzes e do Progresso, uma visão moderna do real como caos, da vida como condenação, isto é, o Inferno é o aqui e agora, somos nós, são os outros e não qualquer entidade sobrenatural. "Parente do conto fantástico", como diz Vax, o tratamento do fantástico em Le Spleen de Paris acentua a transgressão e o escândalo, mas transferindo a ambiguidade do plano da mera questão de se decidir se é real ou sobrenatural para o da afirmação inverosímil de que o real é sobrenatural, tal como 0 sobrenatural pode ser muito familiar. Por outro lado, a ambiguidade verifica-se ainda no plano da diluição das fronteiras entre Bem/Mal, divino/satânico, real/sobrenatural, prosa/poesia. No fundo, nesta obra de Baudelaire, a problemática do fantástico conjuga-se harmoniosamente com os demais aspectos que a caracterizam, servindo para enfatizar o desconcerto íntimo do sujeito enunciativo.

De desconcerto íntimo associado ao imperativo de tentar explicar racionalmente um facto insólito, inverosímil ou mesmo impossível trata também, embora de forma diferente, a terceira obra sobre a qual nos iremos agora deter, o conto Apparition $^{14}$, de Guy de Maupassant (1850-1893), um dos mais conceituados mestres do fantástico.

\footnotetext{
${ }^{14} \mathrm{O}$ conto foi publicado pela $1^{\mathrm{a}}$ vez em Le Gaulois de 04 de Abril de 1883.
} 
De um modo geral, esta narrativa evidencia uma sólida construção, tendo como espinha dorsal a cadeia de eventos à qual, como sucede estruturalmente no conto, é conferida maior importância do que ao tratamento da psicologia da(s) personagem(ns): trata-se de factos ocorridos com ela(s). No entanto, é nítida a preferência por caracteres que, de alguma maneira, se distinguem da massa anónima, não raro por serem protagonistas de um drama insólito. É o caso dos textos fantásticos (e concretamente de Apparition), em que o herói precisa, não obstante, de se apresentar o mais conforme possível a um tipo sociocultural longe de qualquer suspeita. Porquê? Já o dissemos: como forma de conferir verosimilhança aos inverosímeis eventos narrados. Assim, afirma-se verdadeiro algo inconciliável, ou seja, a coabitação de duas ordens paradoxais - de um lado, a ordem do mundo familiar, do real quotidiano; do outro, a ordem do meta-empírico (de carácter negativo), tão plausível quanto a anterior, e que instaura uma ruptura, uma fenda na primeira, perturbando a relação da personagem (e do leitor, que com ela é levado a identificar-se) com as coisas que fazem parte da sua experiência vivencial. Daí o difícil equilíbrio do fantástico, como vimos: um passo em falso para o lado da aceitação da manifestação sobrenatural e cai no maravilhoso; um passo em falso para o lado da explicação racional e cai no estranho. De comum aos três, o fenómeno meta-empírico. Específico do fantástico, a ambiguidade instaurada e constantemente preservada até ao final. Tratando-se de um conto fantástico, cujo tema é o medo (daquilo que não se compreende e que toma posse do indivíduo - um fantasma?/a loucura?), como se constrói aqui a ambiguidade, a débil fronteira entre sobrenatural e razão/alucinação? Seguindo a proposta de F. Furtado, atentaremos em cinco aspectos que funcionam como reforço da plausibilidade, mantendo a dúvida. Ou seja, aqueles que permitem a encenação da leitura ${ }^{15}$ como jogo da ambiguidade. São eles: a construção da verosimilhança do inverosímil a partir de elementos como o papel do narratário, o narrador-actor, a caracterização ambígua das personagens e o tratamento do tempo e do espaço.

O título, Apparition, introduz-nos, de imediato, o motivo central do conto, nomeando a manifestação meta-empírica. A extrema concisão do sintagma nominal, excluindo o substantivo de qualquer determinante, é sintomática do carácter ambíguo da manifestação. Ele (sintagma) irrompe na página tal como ela (aparição) irrompe no real: subitamente, sem explicações. Poderíamos ser levados a pensar que tal clareza representaria uma aceitação do fenómeno sobrenatural, quebrando, assim, a ambiguidade. Contudo, logo na primeira frase da sequência inicial (I Parte) surge o contraponto racional do fenómeno: "On parlait de séquestration à propos d'un procès récent" (Maupassant, 1909: 155, itálicos nossos). Instaura-se, portanto, desde o início, a dúvida, a ambiguidade: a história a que iremos

\footnotetext{
${ }^{15}$ O problema da leitura é aqui considerado a dois níveis: extratextual (o plano do leitor) e intratextual (o plano do herói que tenta descodificar os signos que se lhe apresentam).
} 
assistir é mesmo do domínio de uma ordem sobrenatural ou tem, pelo contrário, uma explicação natural - um sequestro? De facto, somos arrastados de uma para a outra até ao final do texto, não podendo nunca optar exclusivamente por uma das hipóteses.

Esta primeira parte (I) funciona como situação a vários níveis: temático (a explicação residirá num sequestro?), temporal ("à la fin d'une soirée intime"), espacial ("rue de Grenelle, dans un ancien hotel"), social (círculo íntimo de amigos: "le vieux marquis de la TourSamuel"), dados que correspondem à criação do efeito de real, completados por um enquadramento epocal e ideológico (opinião pública) verosímil. Por outro lado, a instância enunciadora apresenta-se como um narrador heterodiegético neutral, que situa, não a história, mas a personagem que lhe dá voz ("le vieux marquis de la Tour-Samuel, âgé de quatre-vingt-deux ans, se leva et vint s'appuyer à la cheminée. II dit de sa voix un peu tremblante"). Testemunha da narrativa do marquês, não pode ter um estatuto de omnisciência, pois tal anularia a ambiguidade. De facto, diz-se: "chacun avait son histoire, une histoire qu'il affirmait vraie" (155, itálicos nossos). A responsabilidade do enunciado é deixada, assim, à personagem, não emitindo o primeiro narrador, o do nível da narrativaquadro, qualquer julgamento, limitando-se a mostrar, a pôr em cena a personagem caracterizada, pelo estatuto social e pela idade, como um indivíduo digno de crédito. Mostrando a quem? A um destinatário extratextual, um narratário que corresponde ao leitor. Para convencê-lo da sua imparcialidade, o estilo adoptado é simples, claro, conciso: frases breves, contendo, porém, o máximo de informação factual e o mínimo de valorização.

A segunda (II) e a terceira (III) partes são da responsabilidade de um narrador de $1^{\underline{a}}$ pessoa ("je sais”), correspondendo a um preâmbulo à narrativa do acontecimento insólito, uma preparação do auditório (II) e à narrativa propriamente dita (III). Assim, quando o velho marquês toma a palavra ("Moi aussi, je sais une chose étrange, tellement étrange, qu'elle a été l'obsession de ma vie", 155), muda o foco narrativo: estamos agora na primeira pessoa e o narrador anterior desaparece totalmente. A instância do destinatário ocorre num duplo nível. Intratextual (o grupo, no qual se destacam as senhoras e se inclui verosimilmente o primeiro narrador), por um lado. Por outro, através da sequência inicial, num outro nível da responsabilidade justamente do primeiro narrador, o enunciado dirige-se a um destinatário extratextual (leitor), como vimos. Este encontra-se, no entanto, em pé de igualdade com aquele: não sabe mais e terá que decidir por si próprio. Aliás, o papel do narratário no texto fantástico é, precisamente, o de mediador entre o narrador e o leitor, funcionando como modelo deste ao ser receptivo à ambiguidade enunciada no discurso. Confrontemos a frase inicial proferida pelo marquês ("je sais une chose étrange", 155) com a sua última ("Je ne sais rien de plus", 168), que fecha o conto, deixando-o, todavia, aberto à livre interpretação de cada um. A última frase reforça, pois, a primeira, não avançando nenhuma explicação para o insólito acontecimento, sustentando, assim, a ambiguidade. 
O marquês surge, então, como um narrador-personagem (autodiegético). Porém, entre o eu-narrador (a voz enunciativa de oitenta e dois anos) e o eu-narrado (o herói de vinte e seis), verifica-se um distanciamento temporal de cinquenta e seis anos, o que consolida a plausibilidade da história, quer pelo respeito merecido pela idade e pelo estatuto social do marquês, quer pela posição céptica por ele assumida (distinção entre "les dangers imaginaires" e "les dangers véritables", 156; "Je ne crois pas aux fantômes", 163), quer ainda pela constância do seu carácter. Porém, após tantos anos continua a não ter explicação racional para o evento insólito: "Je vais vous dire l'aventure telle quelle, sans chercher à l'expliquer. II est bien certain qu'elle est explicable, à moins que je n'aie eu mon heure de folie. Mais non, je n'ai pas été fou, et je vous en donnerai la preuve. Imaginez ce que vous voudrez. Voici les faits tout simples" (156). Com efeito, é a dúvida permanente aquilo que o marcou:

II m'est demeuré de ce jour-là une marque, une empreinte de peur, me comprenezvous? Oui, j'ai subi l'horrible épouvante, pendant dix minutes, d'une telle façon que depuis cette heure une sorte de terreur constante m'est restée dans l'âme. Les bruits inattendus me font tressaillir jusqu'au cœur ${ }^{16}$; les objets que je distingue mal dans l'ombre du soir ${ }^{17}$ me donnent une envie folle de me sauver. J'ai peur la nuit, enfin. (Maupassant, 1909: 155-156)

Toda esta parte preparatória do auditório (II) nos coloca, de imediato, perante um determinado ângulo de visão perspectivador dos acontecimentos. Trata-se de uma focalização restritiva, pois embora exista um distanciamento temporal grande, ele funciona como reforço da ambiguidade e da autoridade do narrador e não como um meio explicativo - isso anularia o carácter fantástico, como já foi referido. Por outro lado, encontramo-nos perante uma focalização interventiva servida por um discurso, apesar de tudo, valorativo ${ }^{18} \mathrm{e}$ modalizante ${ }^{19}$. Tudo é perspectivado através dos sentidos (olfacto, visão, audição e tacto) do herói, o que, ao não excluir a hipótese de uma alteração da percepção do real, favorece uma ambiguização do ponto de vista.

A narrativa do marquês (III) inicia-se com uma situação espacio-temporal que tem como intuito torná-la verosímil: "C'était en 1827, au mois de juillet. Je me trouvais à Rouen en garnison" (157). A primeira função cardinal do conto - reencontro ("je rencontrai un homme", 157) - introduz-nos a personagem responsável, em certa medida, pelo

\footnotetext{
${ }_{17}^{16}$ Indício dos leves ruídos e dos suspiros captados na sequência da aparição.

17 Indício ambíguo da sequência da aparição - cena passada na obscuridade: tudo pode ter sido fruto de uma perturbação dos sentidos.

${ }^{18}$ Cf. "dangers imaginaires" vs. "dangers véritables"; "épouvantables et stupides terreurs"; "je ne crois pas aux fantômes; et bien! j'ai défailli sous la hideuse peur des morts. [...] comme un lâche" (163).

${ }^{19}$ Cf. "Le manoir semblait abandonné depuis vingt ans. [...] II semblait atterré" (160); "comme si on venait [...] les sièges semblaient en déroute. [...] je crus entendre ou plutôt sentir un frôlement derrière moi" (162).
} 
acontecimento. A catálise que se lhe segue explica quem é esse homem: "C'était un ami de jeunesse que j'avais beaucoup aimé" (157). Justifica-se, assim, a verosimilhança da relação de intimidade e o tratamento por tu, bem como o pedido insólito dirigido ao herói-narrador, ao qual este prontamente acede. Esta catálise, através do encaixe da história resumida do amigo relativa aos cinco anos em que estiveram afastados, fornece uma série de elementos capazes de fazer pender o prato da balança um pouco para o lado do sobrenatural. Impera o excesso de valor negativo ${ }^{20}$ : o brusco envelhecimento do amigo provocado pela morte da mulher, uma fatal relação amorosa também ela marcada pelo excesso (157). O amigo é uma personagem estranha e perturbada (158-160) e que irá desaparecer em circunstâncias não explicadas. Ambíguo é, também, o caseiro, agindo de forma muito estranha em relação à entrada do herói-narrador no solar, parecendo saber de algo invulgar: ou a presença efectiva do fantasma feminino ou a presença de uma mulher sequestrada (160).

A caracterização da mulher/aparição não ajuda na resolução do enigma. Como um fantasma convencional, veste-se branco, o que, porém, também é normal em termos de traje de dormir. Quando aparece, a voz é bem material, embora talvez um pouco espectral ("elle parla d'une voix douce et douloureuse qui faisait vibrer les nerfs", 164). A sua "chevelure de glace" (165) também parece material: "ses longs cheveux qui me donnèrent à la peau une sensation de froid atroce comme si j'eusse manié des serpents [...]. / Cette sensation m'est restée dans les doigts et je tressaille en y songeant" (165). A qualificação de pendor sobrenatural, maléfico, depende exclusivamente da percepção do sujeito enunciador que, note-se, está num estado de absoluto pânico ("J'étais éperdu à ne plus savoir ce que je faisais [...]. J'avais peur", 164). Então, ele hesita perante o que vê, ou julga ver, "femme ou spectre" (164). Estranho é, sem dúvida, o aparecimento e o desaparecimento súbitos, assim como o bizarro pedido, simbolicamente erótico: "- Peignez-moi, oh! peignez-moi; cela me guérira; il faut qu'on me peigne. Regardez ma tête... Comme je souffre; et mes cheveux, comme ils me font mal! / [...]. Elle soupirait, penchait la tête, semblait heureuse" (165). O carácter irreal da cena é preparado, contudo, pela descrição precedente do espaço onde tem lugar, marcado pelo hibridismo entre os dados do real, perfeitamente verosímeis, e indícios de subversão (em número muito inferior). Primeiro, apresenta-se uma área isolada, afastada de uma zona urbana, num dia em que o tempo está magnífico (158-159). Depois, passa-se para o solar antigo, desabitado, em ruínas (160). Em seguida, verifica-se a penetração no ambiente interior (161). Por fim, o herói-narrador entra no quarto desabitado, fechado, com cheiro a mofo e mergulhado na escuridão (161). Quando os olhos se habituam, ele nota a desordem, "un lit sans draps, mais gardant ses matelas et ses oreillers, dont l'un portait l'empreinte profonde d'un coude ou d'une tête comme si on venait de se

\footnotetext{
${ }^{20}$ Se bem que possa ser atribuído à perspectiva (perturbada?) da voz narradora - o discurso é modalizado, e é a voz que, em discurso indirecto, reporta a história. Somente mais adiante o amigo tomará a palavra.
} 
poser dessus" e "une porte, celle d'une armoire sans doute ${ }^{21}$, était demeurée entr'ouverte"22 (161-162). Os elementos de subversão, decorrentes, contudo, da percepção da personagem, são modalizados pelo discurso, o que reforça a ambiguidade, assim como a tentativa fracassada de iluminar o quarto (162). Oposto ao espaço ameaçador da ocorrência insólita, do qual foge em pânico (166), é o abrigo do espaço familiar do seu quarto, onde pode, então, tentar compreender: "Certes, j'avais eu un de ces incompréhensibles ébranlements nerveux, un de ces affolements du cerveau qui enfantent les miracles, à qui le Surnaturel doit sa puissance" (166). Contudo, aparece de novo um elemento subversivo, desfazendo a teia lógica, equilibrando novamente os pratos da balança do fantástico: "Et j'allais croire à une vision, à une erreur de mes sens, quand je m'approchai de ma fenêtre. Mes yeux, par hasard, descendirent sur ma poitrine. Mon dolman était plein de cheveux, de longs cheveux de femme qui s'étaient enroulés aux boutons!" (167). Tal materialidade é causa do medo persistente, pois não sabe como explicá-la, assim como o estranho desaparecimento do amigo, procurando-se, através do recurso à justiça, consolidar a autoridade e a verosimilhança (167-168). A narrativa encaixada do marquês termina e encerra o texto, sublinhando a dúvida, a ambiguidade do caso: os fantasmas, como seres sobrenaturais, não costumam deixar cabelos reais; mas também as mulheres de carne e osso não podem desaparecer no ar. Levando em conta que esta figura feminina saiu por uma porta aparentemente real, não é verosímil que um jovem militar não tenha conseguido abri-la ou, em último caso, deitá-la abaixo.

Neste conto, conjugam-se duas linhas de sentido recorrentes em Maupassant: a linha erótico/sensual e a linha da fobia da loucura, que se entretecem no motivo central - a cabeleira feminina. A leitura poderia escolher uma das vias, no entanto, em nossa opinião, elas encontram-se de tal forma entrançadas, que seria redutor não considerar uma certa ambiguidade que se coloca a este nível. De facto, confrontado com a presença (ou a sugestão) de algo para além do racional, o protagonista sente a dúvida instaurar-se em si e, com ela, o medo. Contudo, nada no texto invalida uma outra hipótese interpretativa, a de que o velho marquês esteve todo o tempo a jogar com a credulidade do seu auditório feminino. De acordo com as regras do género fantástico, tanto aqui como nos outros exemplos tratados, decida o leitor aquilo em que quer acreditar.

Em conclusão, podemos dizer que, na narrativa fantástica, os conceitos aristotélicos de verosímil e inverosímil servem para construir um discurso ambíguo, onde o fingimento da verdade está ao serviço de uma literatura da perplexidade inquietante que provoca o medo. De facto, como vimos, o fantástico é, sobretudo, uma questão de percepção: para provocar

\footnotetext{
${ }^{21}$ A certeza será posta em causa mais adiante.

22 Será por aí que o ser desaparecerá, reforçando a ambiguidade textual: "[elle] s'enfuit par la porte que j'avais remarquée entr'ouverte. / [...] Je m'élançai sur la porte par où cet être était parti. Je la trouvai fermée et inébranlable" (165-166).
} 
no leitor o efeito da angústia e do medo, a narrativa fantástica assenta na ambiguidade da apresentação do fenómeno meta-empírico, fingidamente verdadeiro, inserindo, assim, num quadro real verosímil, algo de escandalosamente inverosímil que instaura o paradoxo nos quadros de referência do mundo conhecido, podendo conduzir à loucura ou/e à morte. $\mathrm{O}$ fantástico afasta-se, então, por um lado, da inverosimilhança pressuposta pelo pacto ficcional do maravilhoso, mas ele distancia-se, igualmente, por outro lado, do imperativo da verosimilhança absoluta que, de Aristóteles ao Classicismo (seiscentista e setecentista) e, já no séc. XIX, à estética realista, enforma o pacto ficcional das várias manifestações do "realismo" na literatura francesa e europeia. É na passagem de um código ao outro que poderemos inserir tanto o Sylphe de Crébillon como os exemplos de Le Spleen de Paris de Baudelaire acima estudados, onde a irrupção do sobrenatural, a confirmar-se, acabaria por ser bem aceite, nomeadamente por destruir o tédio da vida quotidiana quer da Condessa, quer do Poeta. No entanto, a narrativa de Maupassant evidencia já uma assunção plena do código do novo género fantástico, jogando com todos os seus aspectos estruturais. Nela, o "efeito de real" mostra-se absolutamente imprescindível de forma a, paradoxalmente, fazer irromper e tornar admissível a aparência sobrenatural dos fenómenos encenados, satisfazendo o delicado equilíbrio da ambiguidade estrutural que caracteriza o género. Justamente porque a sua ambiguidade estrutural, ao impedir a exclusão da hipótese sobrenatural, acaba por, paradoxalmente, a reforçar, o fantástico pode ser considerado como reacção romântica contra os excessos de confiança do racionalismo iluminista, denunciando a curiosidade intelectual como perigosa. "Reacção retrógrada contra o avanço das 'luzes' e o inevitável triunfo da razão ou, pelo contrário, polémica esclarecida sobre uma presumível ruptura dos limites do universo conhecido?", questiona F. Furtado para, de seguida, responder (?): "vago e indeliberado, o fantástico transporta ainda para este plano, mantendo-a, a ambiguidade que Ihe dá forma" (Furtado, 1980: 138). Ou, como no poema em prosa de Baudelaire "Le joueur généreux", Sua Alteza, supostamente o próprio Diabo, explica ao sujeito da narração

l'absurdité des différentes philosophies qui avaient jusqu'à présent pris possession du cerveau humain [...]. [Son Altesse] ne se plaignit en aucune façon de la mauvaise réputation dont elle jouit dans toutes les parties du monde, m'assura qu'elle était, ellemême, la personne la plus intéressée à la destruction de la superstition, et m'avoua qu'elle n'avait eu peur, relativement à son propre pouvoir, qu'une seule fois, c'était le jour où elle avait entendu un prédicateur, plus subtil que ses confrères, s'écrier en chaire: "Mes chers frères, n'oubliez jamais, quand vous entendrez vanter le progrès des lumières, que la plus belle des ruses du diable est de vous persuader qu'il n'existe pas!" (Baudelaire, 1972: 116-117) 


\section{Bibliografia}

ARISTÓteles (1992). Poética. Lisboa: Imprensa Nacional - Casa da Moeda.

BAUDELAIRE, Charles (1972). Le Spleen de Paris: petits poèmes en prose. Paris: Le Livre de Poche/Librairie Générale Française.

BESSIÈRE, Irène (1974). Le récit fantastique: la poétique de l'incertain. Paris: Larousse Université.

Bozzetto, R. et al. (1980). "Penser le fantastique". In: Europe, oㅡ 611 (Les Fantastiques). Paris: Les Editeurs Français Réunis, pp. 26-31.

CASTEX, P.G. (1951). Le conte fantastique en France de Nodier à Maupassant. Paris: José Corti.

CAZOTTE, Jacques (1965). Le Diable amoureux, nouvelle espagnole. In: Romanciers du XVIIle siècle, T.II. Paris: Bibliothèque de la Pléiade / Gallimard.

Communications no 11 (1968). Paris: Seuil.

CRÉBILLON, Claude (1999). "Le Sylphe”. In: CEuvres complètes. Paris: Classiques Garnier Multimédia, t. I, pp. 23-37.

FURTADO, Filipe (1980). A construção do fantástico na narrativa. Lisboa: Livros Horizonte.

MAUPASSANT, Guy de (1909). "Apparition”. In: Clair de Lune (CEuvres Complètes). Paris: Librairie Louis Conard, p. 155-168.

MILnER, Max (1960). Le Diable dans la littérature française, de Cazotte à Baudelaire. Paris: José Corti.

MuCHEMBLED, Robert (2003). Uma história do Diabo (séculos XII a XX). Lisboa: Terramar.

РотосKI, Jean (2002). Manuscrit trouvé à Saragosse. Paris: Gallimard.

SCHNEIDER, Marcel (1985). Histoire de la littérature fantastique. Paris: Fayard.

TODOROV, Tzvetan (1977). Introdução à literatura fantástica. Lisboa: Moraes Editores.

VAX, Louis (1972). A arte e a literatura fantásticas. Lisboa: Arcádia. 